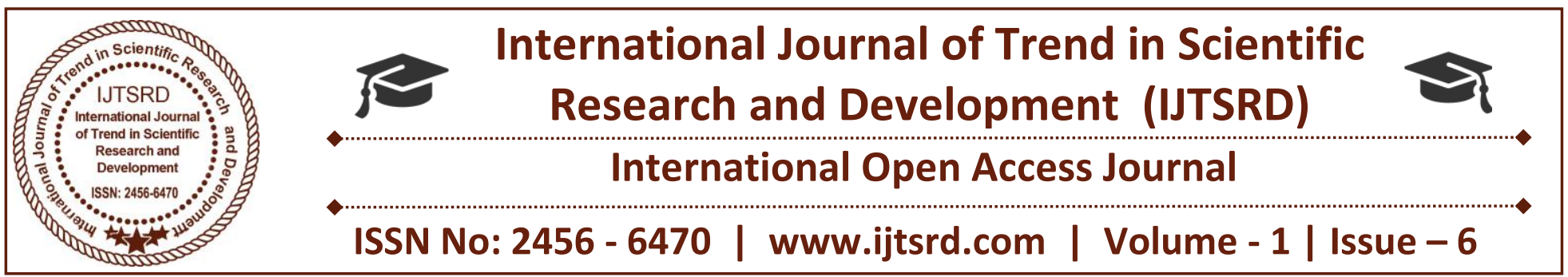

\title{
Factors Affecting the Growth of Women Entrepreneurs in the Construction Industry in Malawi
}

\author{
Divya Manoharan \\ Lecturer-II, School of Commerce and Management, \\ DMI-St. John the Baptist University, The Republic of Malawi
}

\section{ABSTRACT}

This project aims at investigating factors that affecting the growth of women entrepreneurs in Malawi. Malawi being one of the developing countries, women are the backbone of the economy and women play a significant role to ensure the wellbeing of their families. The researcher will adopt a descriptive survey research. A descriptive survey research seeks to obtain information that describes existing phenomena by asking individuals about their perceptions, attitude, behavior or values. The inferential statistics will be used to analyze the collected data. The current research project is affected by a number of limitations including time and financial resources. This researcher will conclude that the major threat to women entrepreneurs is access to finance as well as illiterate which makes it impossible for them to access the finances. It is recommended that that the financial institutions should set some simple ways and soften the requirements of accessing the financial facilities for the women entrepreneurs and give them at reasonable rate to enable them to repay with ease.

Keywords: Factors, Construction Industry, Women Entrepreneurs, Malawi

\section{INTRODUCTION}

Entrepreneurship is increasingly recognized as an important driver of economic growth, productivity, innovation and employment and it is widely accepted as a key aspect of economic dynamism (MulugetaChaneWube, 2010). Transforming ideas into economic opportunities is the decisive issue of entrepreneurship. History shows that economic progress has been significantly advanced by pragmatic people who are entrepreneurial and innovative, able to exploit opportunities and willing to take risks (Hisrich, 2005). According to Oxford, Herrington and Wood (2004: 6), entrepreneurship is an opportunity-driven, pioneering mindset, passion and commitment to your idea, confidence in your ability to achieve results and a willingness to take calculated risks. Malawi being one of the countries in Southern Africa is also affected by these factors. Women are the backbone of the economy and they play a significant role to ensure the well-being of their families (Phizacklea, 2003). The role of women in economic development cannot be understated. Jiggins (1989) notes that about 30 per cent of rural households in the world are headed by women, and that women contribute about 80 per cent of agricultural labour, produce almost 60 percent of the food that is consumed by rural households and generate more than one-third of household incomes, mainly through small-scale agro-industry, trading, craft work and casual labor. In Malawi, about 59 per cent of female proprietors said 50 per cent or more of their household income came from their enterprises (Daniels \& Ngwira,1993). Verwey (2005: 2) mentioned that the Women in Construction (WIC) initiative was originally founded in 1997. WIC later developed into the South African Women in Construction (SAWIC) with some of its objectives to protect women entrepreneurs in construction against discrimination. According to NABW (CIPE, Nov 2011) Women in Malawi face a number of obstacles to taking ownership of their economic future. At least 34 percent of Malawi women are the head of their household. At the same time, those who are married and seek to establish a business must have their 
husband's signature to qualify for a commercial bank loan. Furthermore, 64 percent of women in Malawi live under the poverty line. (NABW, CIPE Report, Nov 2011) In order to take appropriate measures for these problems, the aim of this research is to identify the factors that affect the growth of women entrepreneurs in Malawi especially in the construction industry. According to the database of contractors provided by the Millenium Challenge AccountMalawi (MCA-M) and compiled by the National Construction Industry Council of Malawi (NCIC) is clear as it shows few registered women in the construction sector (April,2015). The analysis of the database shows that there are 777 lists of registered contractors with NCIC out of which 54 companies are owned by women (MCA-M, April 2015). Women entrepreneurs in construction are not optimizing the opportunities in that sector. There is a perception that construction is for men and that women can only explore soft skills in the entrepreneurial sector. The focus of the research is to investigate the challenges women entrepreneurs face to grow and develop their business in the construction industry. The research will also reveal reasons for slow growth and development of women owned businesses in Malawi.

\section{Objectives of the Study}

The main objective of the study is to develop a framework for the growth of women entrepreneurs in the construction industry in Malawi. The issues of globalization are reshaping the international economic landscape and technological change is creating greater uncertainty in the world economy. As a result of this, the dynamism of entrepreneurship is believed to be able to help to meet the new economic, social and environmental challenges that most governments are facing. Governments increasingly consider entrepreneurship and innovation to be the cornerstones of a competitive national economy, and in most countries entrepreneurship policies are in fact closely connected to innovation policies, with which they share many characteristics and challenges. The dynamic process of new firm creation introduces and disperses innovative products, processes and organizational structures throughout the economy. Entrepreneurship objectives and policies differ considerably from country to country, owing to different policy needs and diverse perspectives on what is meant by entrepreneurship.

\section{Women Entrepreneurship}

Entrepreneurs are more likely to be male than female. However, recent survey data show the rate of entrepreneurship activity decreasing for men and increasing for women (from 2007 to 2008, the rate of entrepreneurship among men decreased from 12 percent to 9.8 percent, while it increased for women from 6.1 percent to 7.5 percent). Reasons for differences in entrepreneurship rates between men and women may be due to access to finance, differences in credit scores, and other reasons. Other key differences between male and female entrepreneurs include: Men and women start different types of businesses. Women are nearly twice as likely to start a consumeroriented business as men, whereas men are three times as likely to start businesses in high-technology sectors as women. Men and women are equally likely to establish businesses in the services sector. Women entrepreneurs are also more often represented in retail and less represented in construction (Berlin et al., 2010: 19). Bosma and Levie (2010: 16) argued that for entrepreneurial activity to occur in a country, both opportunities for entrepreneurship and entrepreneurial capabilities need to be present.

\section{Influencing Factors for Women's Under- Representation in the Construction Industry}

Nchimbi and Chijoriga, 2009 states that underrepresentation of WECI in the construction industry is caused by various factors, such as cultural background, choice of business and confidence ( Dainty, Green and Bagihole, 2007). [1]Women's choice of business activities is dictated by their reproductive roles, abilities in terms of education, entrepreneurial capacity and technical skills, limited start-up capital and their limited capacity to absorb the consequences of failure (Langowitz and Minniti, 2007; Nchimbi and Chijoriga, 2009). As a result, they choose activities that can be easily combined with their domestic chores and are culturally acceptable, which refers to self-imposed barriers when women (wrongly) perceive that they may not have the right opportunities and know-how to start and grow their own businesses. Self-perceptions are closely linked to the environment in which entrepreneurship occurs.

\section{Factors that affect the growth of women entrepreneurship in general}

According to Hakala (2008), the barriers/challenges to women in the non-traditional industries are the lack of technical knowledge and lack of confidence and 
ability to make strategic choices to improve their financial position. [2]Entrepreneurs experience these challenges in different sectors and at different stages of their evolution from infancy to maturity (Worrall et al., 2008). In addition to these challenges, the social, cultural norms and beliefs have made patriarchal societies that reinforce continued subordination and marginalisation of many women entrepreneurs (Hodginkson, 2006; Manolova et al., 2007). As a partial result, women have limited access to financial resources and lack the prior entrepreneurial competency, which contribute to the specific challenges of starting and running a business (Orhan and Scott, 2001; Manolova et al., 2007).

\section{Isolation from Business Networks}

Networks are the formal and informal links that exist between individuals, firms and institutions. Partnerships between individuals and firms, among similar firms or across industries, provide access to peers and peer-based learning, financial resources for start-ups, growth and operational support, knowledge, services and other business resources that lead to more innovation. Network forms at a variety of scales between key players of all sizes and functions. [3] The relationships that form between individuals, the base level for brainstorming, idea generation, everyday business advice, and overall support. Entrepreneurs tend to learn best from other entrepreneurs (Berlin et al., 2010: 28).

\section{METHODOLOGY}

\subsection{Population, sample and sampling techniques}

The population of the study will consist of 54 women entrepreneurs who are registered with National Construction Industry Council in Malawi. The sample size will be 10 women entrepreneurs in the construction industry. [4]In order to select the sample of entrepreneurs, Purposive random sampling will be used whereby women entrepreneurs in construction industry in Lilongwe will be selected randomly by taking list of respondents from the National Construction Industry Council's office in Lilongwe.

\subsubsection{Quantitative/Fixed Designs}

Quantitative designs are positivist in orientation and usually involve the collection of quantitative data, giving priority to experimentally orientated investigations such as randomized control trials and quasi-experiments. [5]Fixed designs are theory driven (Robson, 2011) and typically consider statistical aggregates, general tendencies and correlations and statistically significant patterns form the basis of the conclusions drawn.

\subsubsection{Qualitative/Flexible Designs}

In contrast to fixed approaches, flexible designs are constructivist or interpretivist in nature; they do not start from a specific hypothesis and they are less concerned with causal relationships or the rigorous comparison of variables.[6] Instead qualitative designs start with a 'problem' that the researcher wishes to explore. Next, holistic data collection methods and inductive logic are used, with a view to developing 'theories' and shared understandings regarding social phenomena (Mertens, 2010)

\subsubsection{Survey}

According to Collins and Hussey (2009) survey is a method for collecting data in which a sample of respondents are asked a list of carefully structured questions chosen after considerable testing with a view of eliciting reliable responses. [7]The current research intends to identify a statistical relationship between input variables and consumer satisfaction; and ultimately understand how consumer satisfaction will impact sustainability. Generalization of results is critical in the current research, as it in tend to provide a solution to a global concern or issue and surveys capacity to generalize the findings makes it appropriate for the current research. Quantitative data were collected through a survey, a choice that stemmed from the efficiency and prevalence of this data collection tool for learning about people and their behaviours (Bradburn and Sudman, 1979; Dillman, et al. 2009).

\subsubsection{Data Sources}

The researcher will use both primary and secondary sources of data for the study. The secondary data will include information that is obtained mainly from different reports, bulletins, websites and literatures, which are relevant to the theme of this study. This information will be gathered from various sources to complement the survey-based analysis. [8] The primary sources of data will be questionnaires which will be distributed to women entrepreneurs and key informant interviews will be conducted with various experts and players in the construction industry, National Construction Industry Council, Malawi Institute of Engineers, Board of Architects and Quantity surveyors in Malawi as well as Banks and Micro finance institutions. 


\section{CONCLUSION}

Throughout the years there has been a lot of interest in entrepreneurship, more particularly women entrepreneurship. Women should be encouraged to study non-traditional fields such as engineering and science in order to prepare them for a broader range of industry choices, noting that many of the nontraditional fields offered higher growth potential and greater rewards.[9] A small business owner also has more freedom to plan one's personal schedule and to combine work with family life, which is often an important consideration for women. Lower levels of financial literacy and awareness are also of great disadvantage to women entrepreneurs. The development of female entrepreneurship needs support through policies and adequate institutions in many areas, such as education and training, access to credit and financing, access to information, business networks and new technologies.[10] It is therefore the responsibility of the Government, in partnership with other stakeholders, to take the lead and responsibility for establishing institutions and policies aimed at development of women entrepreneurs in the country. Some women entrepreneurs do resist in joining associations, organizations and other networks which is important for the growth of their business. However, this can be resolved by Identifying and defining problems that women entrepreneurs often face when applying for bank loans, explain the common problems women experience in obtaining credit. Research credit schemes that have worked in other countries that would be applicable to women owned businesses.[11] Government and all relevant stakeholders should ensure that resources for programs to foster entrepreneurship are decentralized as well as promoting public awareness of entrepreneurship. Women entrepreneurs should examine the role that the education system could play in developing entrepreneurial skills and attitudes. [12]The country should increase opportunities for the unemployed to create their own jobs through selfemployment schemes, especially women entrepreneurs. It's imperative for women entrepreneurs to make an effort in facilitating networking among firms in order to foster a culture of mutual cooperation and risk-taking. Lastly, National Construction Industry Council of Malawi (NCIC) an umbrella body of all the construction firms should also take a leading role and do more in ensuring that women entrepreneurs in construction industry are assisted both financially and technically in order to promote the growth of their business.

\section{REFERENCE}

1) Malawi: Poverty Reduction Strategy Paper Growth and Development Strategy

2) http://blog.firelightfoundation.org-Patuma Bakes: Women In Malawi Venture into Entrepreneurship

3) American Association for Public Opinion Research, "Best Practices for Survey and Public Opinion Research and Survey Practices AAPOR Condemns," May 1997.

4) Asch, B., personal communications, RAND, Santa Monica, Calif., 2001. Bachman, E., J. Elfrink, and G. Vazzana, "Tracking the Progress of Email vs. Snail-Mail," Marketing Research, Vol. 8, 1996, pp. 31-35.

5) Berrens, P., A. Bohara, H. Jenkins-Smith, C. Silva, and D. Weimer, "The Advent of Internet Surveys for Political Research: A Comparison of Telephone and Internet Samples," 2001. Available at David Weimer's homepage at www.lafollette.wisc.edu/facStaff/ (last accessed October 24, 2001).

6) Bradley, N., "Sampling for Internet Surveys: An Examination of Respondent Selection for Internet Research," Journal of the Market Research Society, Vol. 41, 1999, pp. 387-395.

7) Comley, P., "Internet Surveys: The Use of the Internet as a Data Collection Method," ESOMAR/EMAC: Research Methodologies for "The New Marketing" Symposium, ESOMAR Publication Services, Vol. 204, 1996, pp. 335346.

8) Coomber, R., "Using the Internet for Survey Research," Sociological Research Online, Vol. 2, 1997, pp. 14-23. Couper, M. P., "The Promises and Perils of Web Surveys," presentation, RAND, Santa Monica, Calif., July 12, 2001.

9) Everingham, S., personal communication, RAND, Santa Monica, Calif., 2001.

10) Flemming, G., and M. Sonner, "Can Internet Polling Work? Strategies for Conducting Public Opinion Surveys Online," paper prepared for the annual meeting of the American Association for Public Opinion Research, Montreal, Que., May 13-16, 1999.

11) Groves, R., Survey Errors and Survey Costs, New York: John Wiley \& Sons, 1989.

12) Henry, G. T., Practical Sampling, Applied Social Research Methods Series, Vol. 21, Newbury Park, Calif.: SAGE Publications, 1990. 